\title{
Pengembangan Konsep Desain dan Fabrikasi Mesin Penyortir Buah Duku (Lansium Parasiticum)
}

\author{
(The Development Of The Design Concept And Fabrication Of The Duku Fruit Sorter \\ Machine) \\ Satriawan Dini Hariyanto ${ }^{a}$, Rela Adi Himarosa ${ }^{b}$, Andreas Brian Aditya $^{a}$, Sandy Hidayat ${ }^{a}$, Eko Sulistyo \\ Wibowo $^{a}$, Disa Nandy Krisnansia ${ }^{a}$ \\ a Jurusan Teknik Mesin IST AKPRIND Yogyakarta \\ Komplek Balapan, Kota, Jl. Kalisahak No.28, Klitren, Gondokusuman, D.I. Yogyakarta, 55222, Indonesia \\ e-mail: satriawan@akprind.ac.id \\ ${ }^{\mathrm{b}}$ Mechanical Engineering Department, Universitas Muhammadiyah Yogyakarta \\ Jl. Brawijaya, Tamantirto, Kasihan, Bantul, Yogyakarta, Indonesia 55183 \\ e-mail: rela.himarosa@umy.ac.id
}

\begin{abstract}
Abstrak
Pengembangan konsep desain mesin penyortir buah duku (Lansium Parasiticum) dilakukan menggunakan metode Five Step Method. Diperoleh tiga konsep mesin yang kemudian dipilih satu dari tiga konsep terbaik menggunakan metode product champion dilanjutkan dengan pembuatan desain 3D dan Finite Element Analysis (FEA) menggunakan software autodesk inventor 2017. Analisis FEA menunjukkan nilai von Misses stress sebesar $18 \mathrm{MPa}$ bernilai lebih kecil dibanding yield strength material penyusun rangka sebesar $207 \mathrm{MPa}$, displacement yang terjadi sebesar $0,99 \mathrm{~mm}$ dengan nilai safety factor 15 . Fabrikasi dan pengujian mesin menunjukkan nilai persentase keberhasilan proses penyortiran pada mesin lebih dari $85 \%$ dengan kapasitas sortir 400 $\mathrm{kg} / \mathrm{jam}$.
\end{abstract}

Kata kunci: penyortir duku, FEA, Lansium parasiticum

\begin{abstract}
Concept design development of a Lansium parasiticum sorting machine was carried out using five-step method. The best one of three concepts was selected using product champion method. 3D design and finite element analysis (FEA) using Autodesk Inventor 2017 software was conducted to the frame structure of selected machine design. FEA analysis shows that the von Misses stress of $18 \mathrm{MPa}$ lower than yield strength of the frame materials, the displacement value of $0.99 \mathrm{~mm}$ at a safety factor of 15 . Fabrication and machine testing shows that the proportion value for the sorting process on the machine is more than $85 \%$ with a sorting capacity of $400 \mathrm{~kg} / \mathrm{hour}$.
\end{abstract}

Keywords: sorter machine, FEA, Lansium parasiticum

\section{Pendahuluan}

Indonesia memiliki potensi untuk menghasilkan berbagai macam hasil perkebunan khususnya produk buah-buahan. Perkebunan buah duku (Lansium parasiticum) tersebar di seluruh wilayah Indonesia dan merupakan salah satu komoditas yang memiliki potensi untuk dikembangkan. Beberapa contoh wilayah yang menghasilkan komoditas buah duku antara lain perkebunan buah duku di Desa Kalikajar, Kecamatan Kaligondang Kabupaten Purbalingga, Jawa Tengah yang memiliki jumlah pohon duku produktif sebanyak 300 pohon dengan nilai produksi rata-rata perpohonnya mencapai 75 kilogram atau dapat diperkirakan mencapai 22,5 ton pertahun. Selain itu, produksi buah duku di Kecamatan Tanjung Lubuk dan Sirah Pulau Padang Kabupaten OKI Sumatera Selatan terdapat 34425 pohon dan 26115 pohon dengan produksi 690 ton dan 543,7 ton [1]. 
Kendala yang banyak ditemui oleh petani buah duku salah satunya adalah penanganan buah pascapanen khususnya pada proses penyortiran ukuran buah duku. Penyortiran dilakukan untuk memisahkan kualitas buah yang ditinjau dari aspek ukuran dan kondisi fisik. Kegiatan penyortiran buah duku sering dilakukan secara manual dengan mengandalkan pengamatan visual untuk pemilihan kualitas buah tanpa menggunakan peralatan khusus. Metode manual ini memiliki keunggulan dari segi harga yang ekonomis, tetapi memiliki kekurangan yang disebabkan oleh berbagai faktor seperti kelelahan yang dialami oleh operator yang berakibat pada tidak konsistennya kualitas hasil peyortiran. Untuk menaikkan kapasitas dan kualitas penyortiran, salah satu cara yang dapat dilakukan adalah dengan proses otomasi menggunakan mesin penyortir untuk menggantikan metode manual.

Beberapa jenis mesin penyortir buah duku yang sudah ada di pasaran, yaitu mesin sortasi buah duku dengan prinsip bidang miring dan mesin penyortir duku dengan kerucut berputar. Mesin sortasi buah duku dengan prinsip bidang miring memiliki kelebihan pada aspek kapasitas kerja sortir yang cukup baik yakni $500 \mathrm{~kg} / \mathrm{jam}$, tetapi memiliki kekurangan pada tingkat keberhasilan sortir yang masih rendah yakni 59,5\%, dan menimbulkan kerusakan pada buah duku saat proses penyortiran [2]. Mesin penyortir duku dengan kerucut berputar memiliki tingkat keberhasilan sortir mencapai $88,4 \%$, tetapi memiliki kekurangan yang mengakibatkan rusaknya buah duku karena terjepit sehingga memicu rusaknya buah. Selain itu, nilai ketercampuran buah antara beragam ukuran diameter sebesar 9,9\%, dan kapasitas rata-rata proses penyortiran sebesar $111.81 \mathrm{~kg} / \mathrm{jam}$ [3]. Penelitian ini bertujuan mengembangkan tiga konsep desain mesin penyortir buah duku (Lansium Parasiticum) menggunakan metode five step method. Konsep terbaik kemudian dianalisis menggunakan fitur Finite Element Analysis (FEA) yang ada di software Inventor Profesional 2017. Selain itu, fabrikasi juga dilakukan untuk menguji tingkat keberhasilan proses penyortiran mesin berdasarkan desain konsep terpilih.

\section{Metode}

\subsection{Pengembangan Konsep Desain}

Pengembangan konsep desain mesin dilakukan menggunakan metode five step method [4]. Metode five step method dipilih karena keandalannya dalam memetakan permasalahan yang ditemui dalam proses pengembangan konsep. Tahapan pengembangan konsep desain ditunjukkan pada Gambar 2.1.

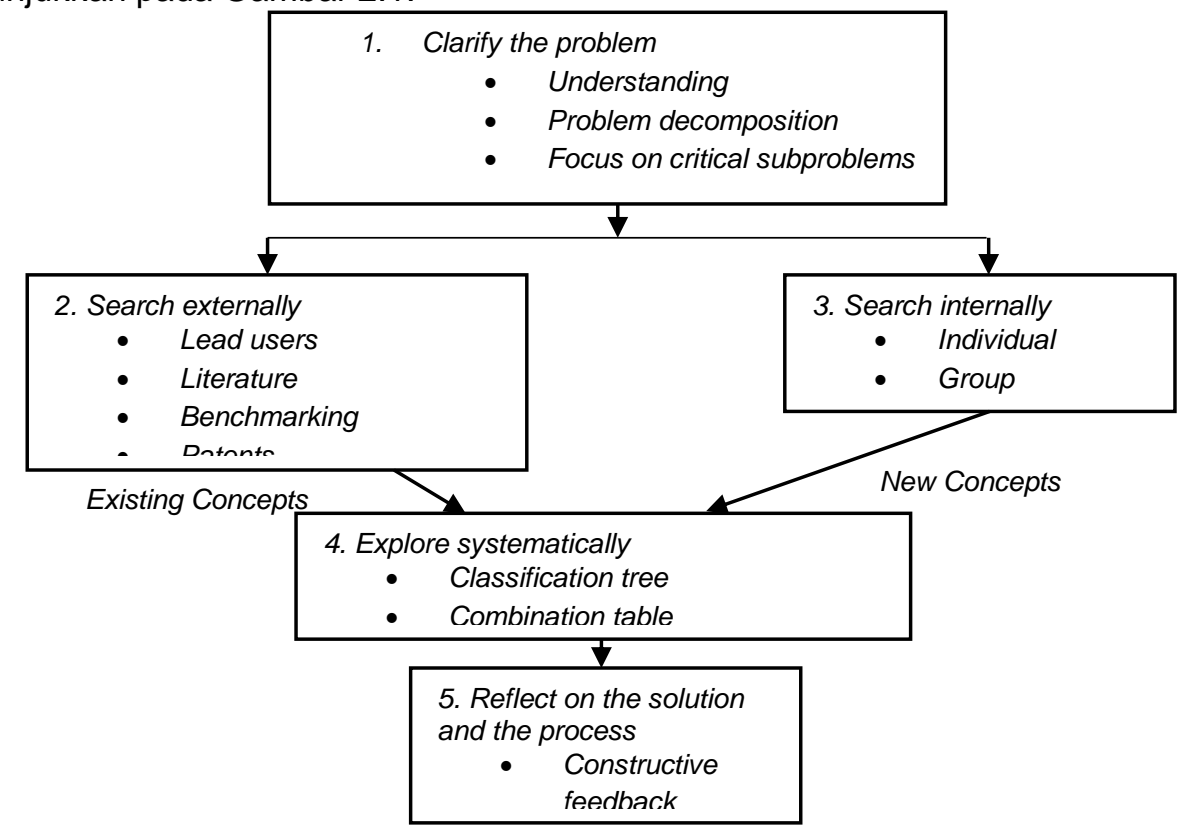

Gambar 2.1 five step method

Proses pengembangan konsep diawali dengan menelaah dan memetakan permasalahan yang ada (clarify the problem). Permasalahan yang muncul dalam perancangan mesin 
pensortir buah duku ini berasal dari kendala yang ditemui pada mesin-mesin penyortir yang sudah ada sebelumnya. Ada beberapa obyek permasalahan yang teridentifikasi dari telaah mesin yang sudah ada, di antaranya keberhasilan kesesuaian hasil penyortiran pada rentang $59,5 \%-88,4 \%$, kerusakan yang muncul pada buah saat proses pensortiran, dan ketercampuran berbagai kualitas (grade) buah duku. Dari permasalahan tersebut, proses selanjutnya adalah mencari data spesifikasi mesin yang lebih mendetail dari sumber eksternal (search externally). Pada penelitian ini, sumber eksternal yang digunakan adalah literatur, paten, dan benchmarking dari produk yang sudah pernah ada. Tahapan ketiga adalah identifikasi data yang telah diperoleh dari tahap kedua. Pada tahap ketiga ini, (search internally) dilakukan telaah dan brainstorming untuk menentukan karakteristik konsep produk yang akan dihasilkan. Tahap keempat dari metode five step method adalah proses eksplorasi secara sistematis (explore systematically) dari hasil brainstorming yang sudah dilakukan. Tahapan ini menghasilkan tiga konsep produk berbeda dalam bentuk sketsa mesin. Tahap ke lima adalah proses pemilihan satu konsep terbaik dari tiga konsep yang sudah diperoleh sebelumnya. Pada tahap ini, dilakukan penentuan spesifikasi final mesin penyortir buah duku sebelum difabrikasi, kemudian konsep terpilih dibuat model tiga dimensi (digital prototyping) menggunakan software desain 3D (Autodesk Inventor 2017) untuk pengujian pembebanan rangka menggunakan simulasi Finite Element Analysis (FEA). Setelah proses simulasi pembebanan, tahapan berikutnya adalah fabrikasi dan dilanjutkan dengan pengujian untuk mengetahui persentase keberhasilan proses sortir dari mesin yang telah difabrikasi.

\subsection{Metode Pemilihan Bahan Bodi Mesin}

Pemilihan material pada konsep desain mesin penyortir duku dilakukan dengan menggunakan metode digital logic. Metode digital logic digunakan untuk memilih material penyusun bodi mesin, adapun database material yang digunakan terlihat pada Tabel 1 . Dalam metode digital logic, keunggulan properti tiap kandidat material dikomparasikan satu sama lain kemudian sejumlah keputusan dinormalisasikan dalam bentuk angka positif dicantumkan dan diskalakan untuk mendapatkan pecahan bobot, sehingga setiap kandidat material memiliki nilai maksimal sebesar satu untuk setiap sifat mekanik (mechanical properties) [5].

Tabel 1 Database material [6]

\begin{tabular}{|l|l|l|}
\hline $\begin{array}{l}\text { Toughness } \\
\text { Strength }\end{array}$ & Density - Modulus & Strength - Density \\
\hline Zinc Alloys & Mg Alloys & Lead Alloys \\
\hline Mg Alloys & Zinc Alloys & Copper Alloys \\
\hline Lead Alloys & Cu Alloys & Ni Alloys \\
\hline Al Alloys & Steels & Steels \\
\hline Cu Alloys & Ni Alloys & Ti Alloys \\
\hline Ni Alloys & Ti Alloys & Al Alloys \\
\hline Steels & W Alloys & Zinc Alloys \\
\hline Low Alloys Steels & Lead Alloys & Tungsten Alloys \\
\hline W Alloys & Al Alloys & \\
\hline Carbon Steels & B C & \\
\hline Ti Alloys & SIC & \\
\hline Cast Iron & & \\
\hline
\end{tabular}

\subsection{Metode Simulasi FEA (finite element analysis)}

Penerapan Finite Element Analysis (FEA) untuk menganalisis struktur rangka menggunakan software autodesk inventor dilakukan untuk jenis struktur yang kompleks [7]. Simulasi pembebanan FEA terhadap desain rangka mesin dilakukan dalam tiga tahap, yaitu preprocessing, processing, dan post-processing. Ketiga tahapan tersebut dilakukan secara 
berurutan dengan menggunakan software autodesk inventor 2017. Tahapan pre-processing merupakan tahap pembuatan desain tiga dimensi rangka dengan memanfaatkan fitur frame generator. Selanjutnya, dilanjutkan dengan tahap processing yang meliputi penentuan lokasi pembebanan, penempatan constraint, penentuan besar pembebanan,pengaturan mesh dan running analysis. Tahap post processing merupakan tahapan terakhir yang berhubungan dengan intrepretasi data hasil simulasi FEA yang telah dilakukan. Pada tahap post processing, diperoleh data berupa nilai tegangan von Misses, safety factor, dan besar displacement yang terjadi pada rangka [8],[9],[10]. Pemodelan FEA menggunakan software autodesk inventor 2017 merupakan pendekatan sifat fisik komponen struktur dengan asumsi material dalam model bersifat homogen dengan respon linier terhadap tegangan [11],[12].

\section{Hasil dan Pembahasan}

\subsection{Pengembangan Konsep Menggunakan five step method}

Pada penelitian ini, pengembangan konsep desain menggunakan metode five step method menghasilkan tiga jenis konsep mesin pensortir buah duku, yaitu mesin penyortir dengan multisilinder (Gambar 3.1), mesin penyortir dengan alur v-belt (Gambar 3.2), dan mesin penyortir dengan satu silinder (Gambar 3.3).

\section{1a Konsep 1 (Mesin pensortir dengan multi silinder)}

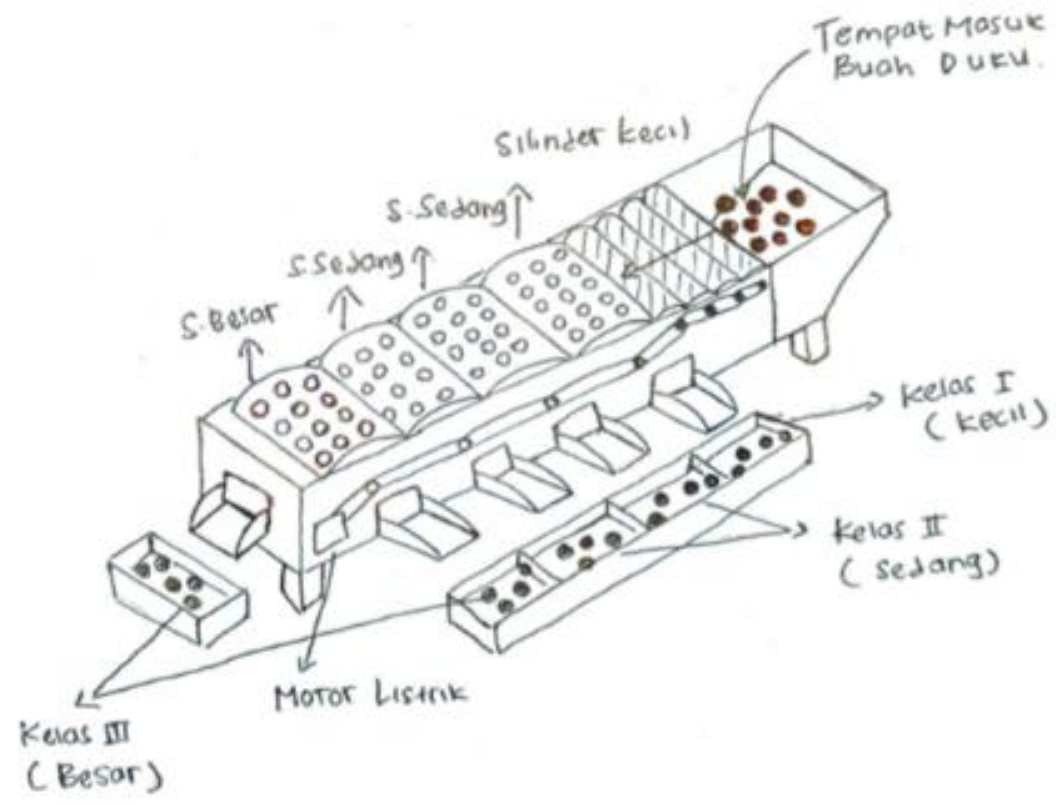

Gambar 3.1 Sketsa mesin penyortir dengan multi silinder

Konsep mesin multisilinder berputar memiliki keunggulan dari segi banyaknya kapasitas pensortiran yang dapat dilakukan. Akan tetapi, kelemahan konsep desain ini terletak pada kemungkinan tingkat kerusakan buah yang cukup tinggi karena terhimpit silinder yang berotasi. Kekurangan lainnya yang mungkin terjadi pada konsep mesin penyortir jenis ini adalah fleksibilitas pengaturan besarnya diameter buah duku yang dapat disortir.

\section{1b Konsep 2 (Mesin penyortir duku dengan alur $\mathbf{v}-$ belt)}

Konsep mesin penyortir duku dengan alur v-belt memiliki keunggulan pada minimnya kontak antara buah dengan komponen mesin yang bergerak sehingga peluang buah untuk mengalami kerusakan saat proses sortasi lebih rendah dibandingkan dengan konsep mesin penyortir multisilinder. Proses sortasi berlangsung menggunakan gerakan translasi v-belt yang memiliki jarak semakin besar seiring dengan semakin panjangnya lintasan sortasi yang 
digunakan. Konsep mesin jenis ini memiliki keunggulan dari segi rentang ukuran diameter buah duku (Lansium parasiticum) yang dapat disortir lebih luas dibandingkan konsep mesin penyortir berbasis silinder.

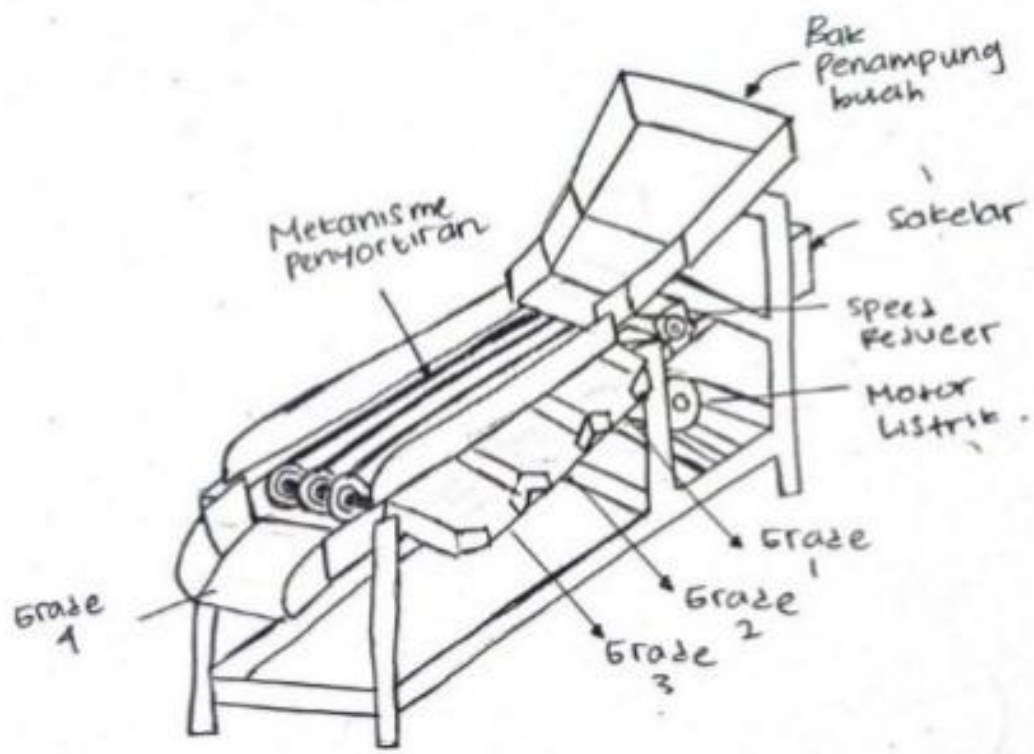

Gambar 3.2 Sketsa mesin penyortir duku dengan alur v-belt

\section{1c Konsep 3 (Mesin penyortir duku dengan satu silinder)}

Konsep mesin penyortir dengan satu silinder berputar beroperasi dengan memanfaatkan gerakan berputar silinder dan bidang miring. Buah duku akan bergerak ke arah lintasan yang lebih rendah dari sisi dalam silinder berputar, kemudian buah duku akan tersortir melewati lubang-lubang yang dibuat sesuai kategori ukuran diameter. Kelebihan dari konsep mesin ini terletak pada konstruksinya yang sederhana dan memiliki kapasitas penyortiran yang besar. Akan tetapi, kelemahan konsep tersebut terletak pada rendahnya efisiensi kesesuaian hasil sortir terhadap grade yang ditentukan.

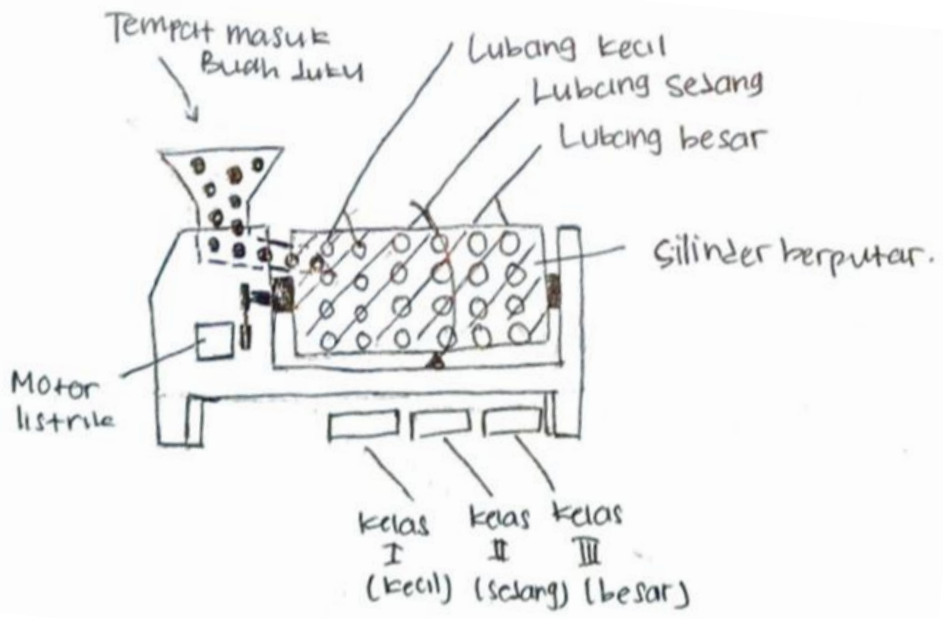

Gambar 3.3 Sketsa mesin penyortir duku dengan satu silinde

Pemilihan konsep terbaik dari tiga konsep yang berhasil dibuat dilakukan berdasarkan metode product champion [4]. Metode product champion dilakukan dengan membandingkan 
tiap-tiap konsep dengan preferensi keunggulan dan kekurangan yang dikemukakan oleh tim perancang. Berdasarkan metode tersebut, konsep kedua (mesin penyortir duku dengan alur v-belt) terpilih sebagai konsep terbaik. Hasil digital prototyping dari konsep terpilih ditunjukkan oleh Gambar 3.4. Komponen penyusun mesin ditunjukkan pada Tabel 3.1.

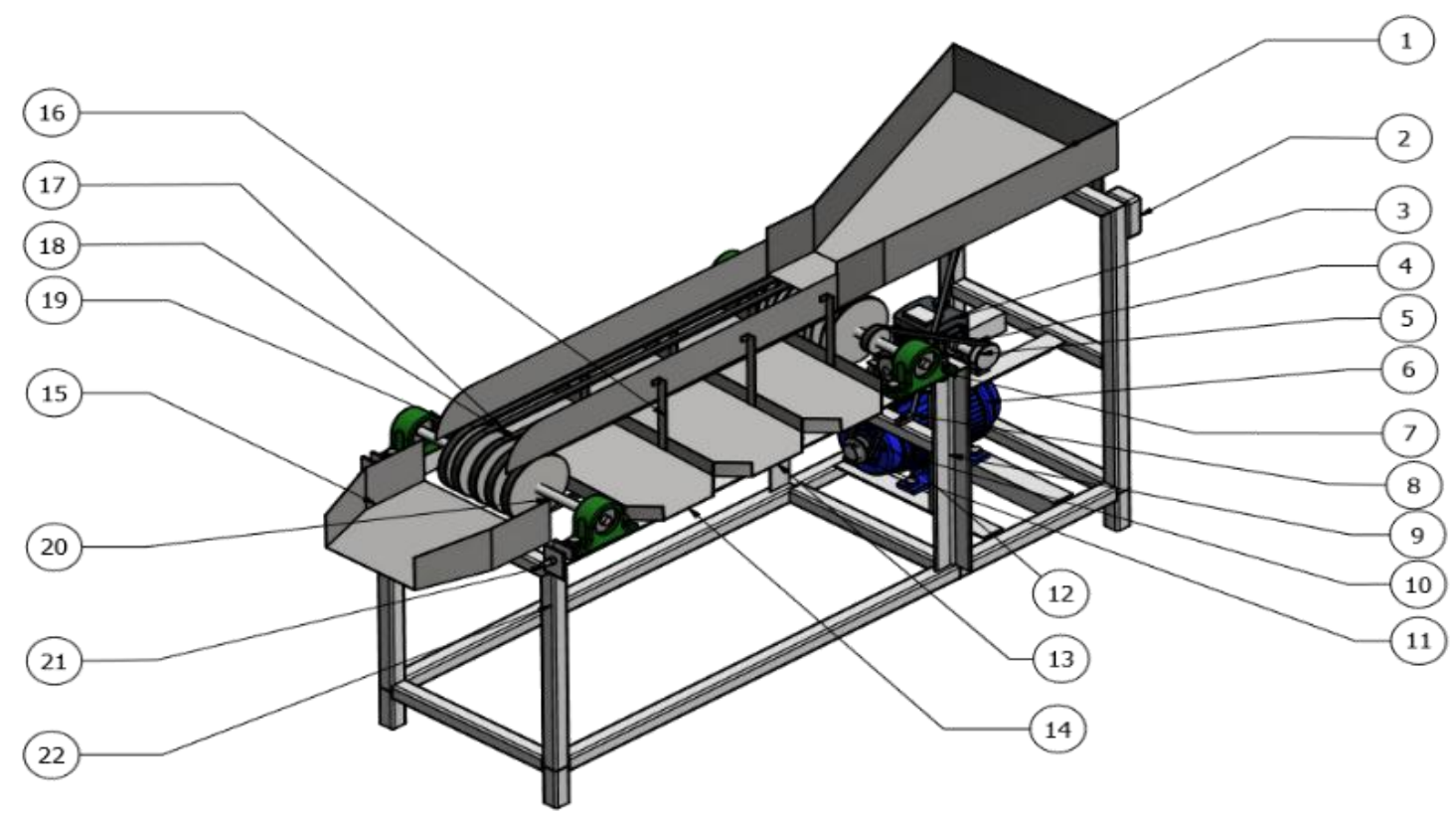

Gambar 3.4 Digital prototyping mesin pensortir duku dengan alur v-belt

Tabel 3.1 Komponen penyusun mesin peyortir buah duku

\begin{tabular}{cccc}
\hline Nomor & Keterangan Gambar & Nomor & Keterangan Gambar \\
\hline 1 & Penampung (Hopper) & 12 & Penampung grade 1 \\
2 & Saklar & 13 & Penampung grade 2 \\
3 & Speed reducer & 14 & Penampung grade 3 \\
4 & V-belt & 15 & Penampung grade 4 \\
5 & Pulley & 16 & Penyangga pelindung \\
6 & Motor Listrik & 17 & Pulley \\
7 & Bantalan & 18 & V-belt pensortir \\
8 & Penyangga hopper & 19 & Pelindung \\
9 & Besi siku & 20 & Poros \\
10 & Sabuk -V & 21 & Spanner \\
11 & Pulley & 22 & Besi hollow profile
\end{tabular}

\subsection{Perhitungan Digital Logic}

Sifat material yang dipertimbangkan untuk diterapkan di dalam proses perancangan ditentukan oleh persyaratan fungsional material. Selain itu, batasan minimum sifat mekanis material dipilih sesuai kategori higher the better dan smaller the better. Berdasarkan hal tersebut diperoleh beberapa material terpilih dari database (Tabel 3.2) yang akan dihitung kelayakannya untuk menjadi komponen penyusun bodi mesin penyortir.

Tabel 3.2 Data mechanical properties material [6] 


\begin{tabular}{|c|c|c|c|c|}
\hline \multirow[b]{2}{*}{ Nama Bahan } & \multicolumn{4}{|c|}{ Sifat - Sifat Bahan } \\
\hline & $\begin{array}{l}\text { Toughness } \\
\left(\text { MPa.m } m^{\frac{1}{2}}\right)\end{array}$ & $\begin{array}{c}\text { Strength } \\
(\mathrm{MPa})\end{array}$ & Density $\left(M g / m^{3}\right)$ & $\begin{array}{l}\text { Modulus } \\
\text { ( GPa) }\end{array}$ \\
\hline Zinc Alloys & 26 & 53,1 & 7,78 & 54 \\
\hline Al Alloys & 47,5 & 95 & 2,70 & 70 \\
\hline Ni Alloys & 59 & 74,6 & 8,8 & 76 \\
\hline Steels & 78 & 98,7 & 5,4 & 65 \\
\hline \multirow[t]{2}{*}{ Ti Alloys } & 40,2 & 88 & 4,51 & 76 \\
\hline & $(\mathrm{MAX})$ & $(\mathrm{MAX})$ & $(\mathrm{MIN})$ & $(\mathrm{MIN})$ \\
\hline
\end{tabular}

Hasil proses normalisasi data pada Tabel 3.2 menghasilkan data normal untuk kategori material yang memiliki sifat kuat, tangguh, ringan, dan kaku. Data lengkap mengenai hasil normalisasi ditunjukkan pada Tabel 3.3.

Tabel 3.3 Data normalisasi mechanical properties material

\begin{tabular}{|c|c|c|c|c|c|c|c|c|}
\hline \multirow{3}{*}{ Property } & \multicolumn{6}{|c|}{ Number of positive decision $N=n(n-1) / 2$} & Positife & Relative \\
\hline & 1 & 2 & 3 & 4 & 5 & 6 & \multirow{2}{*}{$\begin{array}{c}\text { Decision } \\
\text { (m) }\end{array}$} & \multirow{2}{*}{$\begin{array}{c}\text { Emphasis } \\
\text { Coefficient } \\
\alpha\end{array}$} \\
\hline & $1 / 2$ & $1 / 3$ & $1 / 4$ & $2 / 3$ & $2 / 4$ & $3 / 4$ & & \\
\hline Kuat & 1 & 0 & 1 & & & & 2 & 0.34 \\
\hline Tangguh & 0 & & & 1 & 1 & & 2 & 0.34 \\
\hline Ringan & & 1 & & 0 & & 0 & 1 & 0.16 \\
\hline Kaku & & & 0 & & 0 & 1 & 1 & 0.16 \\
\hline \multicolumn{7}{|c|}{ Total Number of Positive Descisions ( N ) } & 6 & $\sum \boldsymbol{\alpha}=1$ \\
\hline
\end{tabular}

Perhitungan nilai $\beta$ dan $Y$ :

a. Menghitung $\beta$ ( scaled property )

Diketahui :

- Nilai max toughness : 78 MPa.m. ${ }^{\frac{1}{2}}$

- Nilai max strength : $98,7 \mathrm{MPa}$

(Steels)

(Steels )

- Nilai min density $\quad: \quad 2,70 \mathrm{Mg} / \mathrm{m}^{3}$

( Al Alloys )

- Nilai min modulus : $54 \mathrm{GPa}$

(Zinc Alloys )

Maka :

- Toughness stainless steels $\beta$ : 100

- Strength stainless steels $\beta \quad: 100$

- Density al alloys $\beta \quad: 100$

- Modulus zinc alloys $\beta \quad: 100$

Rumus menghitung $\beta$ Max dan $\beta$ Min ditunjukkan oleh Persamaan (1) dan Persamaan (2).

$$
\begin{aligned}
& \beta_{\text {Max }}=\frac{\text { Nilai bahan }}{\text { Nilai max kandidat }} \times 100 \\
& \beta_{\text {Min }}=\frac{\text { Nilai min } \text { kandidat }}{\text { Nilai } \text { bahan }} \times 100
\end{aligned}
$$

Nilai $\beta$ toughness :

Zinc Alloys $\beta_{\text {Max }}=\frac{26}{78} \times 100=33,33$ MPa.m $m^{\frac{1}{2}}$

Al Alloys $\beta_{\text {Max }}=\frac{47,5}{78} \times 100=60,89$ MPa.m $m^{\frac{1}{2}}$ 
Ni Alloys $\beta_{\text {Max }}=\frac{59}{78} \times 100=75,64$ MPa. $m^{\frac{1}{2}}$

Steels $\beta_{\text {Max }}=\frac{78}{78} \times 100=100$ MPa. $m^{\frac{1}{2}}$

Ti Alloys $\beta_{\text {Max }}=\frac{40,2}{78} \times 100=51,53$ MPa. $m^{\frac{1}{2}}$

Nilai $\beta$ strength :

Zinc Alloys $\beta_{\text {Max }}=\frac{53,1}{98,7} \times 100=53,7 \mathrm{MPa}$

Al Alloys $\beta_{\text {Max }}=\frac{95}{98,7} \times 100=96,2 \mathrm{MPa}$

Ni Alloys $\beta_{\operatorname{Max}}=\frac{74,6}{98,7} \times 100=75,58 \mathrm{MPa}$

Steels $\beta_{\text {Max }}=\frac{98,7}{98,7} \times 100=100 \mathrm{MPa}$

Ti Alloys $\beta_{\text {Max }}=\frac{88}{98,7} \times 100=89,15 \mathrm{MPa}$

Nilai $\beta$ Density :

Zinc Alloys $\beta_{\text {Min }}=\frac{2,70}{7,78} \times 100=34,7 \mathrm{Mg} / \mathrm{m}^{3}$

Al Alloys $\beta_{\text {Min }}=\frac{2,70}{2,70} \times 100=100 \mathrm{Mg} / \mathrm{m}^{3}$

Ni Alloys $\beta_{\text {Min }}=\frac{2,70}{8,8} \times 100=30,68 \mathrm{Mg} / \mathrm{m}^{3}$

Steels $\beta_{\text {Min }}=\frac{2,70}{5,4} \times 100=50 \mathrm{Mg} / \mathrm{m}^{3}$

Ti Alloys $\beta_{\text {Min }}=\frac{2,70}{4,51} \times 100=59,86 \mathrm{Mg} / \mathrm{m}^{3}$

Nilai $\beta$ Modulus :

Zinc Alloys $\beta_{\text {Min }}=\frac{54}{54} \times 100=100 \mathrm{GPa}$

Al Alloys $\beta_{\text {Min }}=\frac{54}{70} \times 100 \quad=77,14 \mathrm{GPa}$

Ni Alloys $\beta_{\text {Min }}=\frac{54}{76} \times 100 \quad=71,05 \mathrm{GPa}$

Steels $\beta_{\text {Min }}=\frac{54}{65} \times 100 \quad=83,07 \mathrm{GPa}$

Ti Alloys $\beta_{\text {Min }}=\frac{54}{76} \times 100 \quad=71,05 \mathrm{GPa}$

b. Menghitung $Y$ ( performnce index $)$

Diketahui : $-\alpha_{\text {Toughness }}: 0,34$

- $\alpha_{\text {Strength }}: 0,34$

- $\alpha_{\text {Density }}: 0,16$

- $\alpha_{\text {Modulus }}: 0,16$

Rumus menghitung performance index :

$\mathrm{Y}_{\text {Material }}=\left(\alpha_{\text {Toughness }} \cdot \beta_{\text {Toughness }}\right)+\left(\alpha_{\text {Strength }} \cdot \beta_{\text {Strength }}\right)+$

$\left(\alpha_{\text {Density }} \cdot \beta_{\text {Density }}\right)+\left(\alpha_{\text {Modulus }} \cdot \beta_{\text {Modulus }}\right)$.

Menghitung $\mathrm{Y}$ zinc alloys :

$\mathrm{Y}_{\text {Zinc Alloys }}=(0,34 \cdot 33,33)+(0,34 \cdot 53,7)+(0,16 \cdot 34,7)+(0,16 \cdot 100)=51,14$

$\mathrm{Y}_{\text {Al Alloys }}=(0,34 \cdot 60,89)+(0,34 \cdot 96,2)+(0,16 \cdot 100)+(0,16 \cdot 77,14)=81,75$

$\mathrm{Y}_{\text {Ni Alloys }}=(0,34 \cdot 75,64)+(0,34 \cdot 75,58)+(0,16 \cdot 30,68)+(0,16 \cdot 71,05)=67,69$

$\mathrm{Y}_{\text {Steels }}=(0,34 \cdot 100)+(0,34 \cdot 100)+(0,16 \cdot 50)+(0,16 \cdot 83,07)=89,29$

$\mathrm{Y}_{\text {Ti Alloys }}=(0,34 \cdot 51,53)+(0,34 \cdot 89,15)+(0,16 \cdot 59,86)+(0,16 \cdot 71,05)=68,77$

Kemudian didapatkan hasil perhitungan $\beta$ dan $Y$ pada Tabel 3.4

Tabel 3.4 Hasil perhitungan $\beta$ dan $Y$ 


\begin{tabular}{|c|c|c|c|c|c|}
\hline \multirow{2}{*}{$\begin{array}{l}\text { Material } \\
\text { Property }\end{array}$} & \multicolumn{4}{|c|}{ Scaled property ( $\beta)$} & \multirow{2}{*}{$\begin{array}{l}\text { Performnce } \\
\text { Index } \\
\text { ( Y ) }\end{array}$} \\
\hline & Toughness & Strength & Density & Modulus & \\
\hline Zinc Alloys & 33,33 & 53,7 & 34,7 & 100 & 51,14 \\
\hline Al Alloys & 60,89 & 96,2 & 100 & 77,14 & 81,75 \\
\hline Ni Alloys & 75,64 & 75,58 & 30,68 & 71,05 & 67,69 \\
\hline Steels & 100 & 100 & 50 & 83,07 & 89,29 \\
\hline Ti Alloys & $\begin{array}{l}51,53 \\
\text { (MAX) }\end{array}$ & $\begin{array}{l}89,15 \\
\text { (MAX) }\end{array}$ & $\begin{array}{l}59,86 \\
(\mathrm{MIN})\end{array}$ & $\begin{array}{l}71,05 \\
(\mathrm{MIN})\end{array}$ & 68,77 \\
\hline
\end{tabular}

Dari analisis perhitungan penentuan matrial dapat disimpulkan bahwa, material yang cocok digunakan untuk komponen bodi mesin adalah Steels dengan nilai $Y$ terbesar yaitu 89,29.

\subsection{Simulasi Pembebanan Menggunakan FEA}

Simulasi pembebanan dilakukan pada rangka mesin yang sebelumnya telah dirancang dalam bentuk model tiga dimensi menggunakan software autodesk inventor profesional 2017. Data properti mekanik dari material rangka ditunjukkan pada Tabel 3.5.

\begin{tabular}{lll}
\multicolumn{3}{l}{ Tabel 3.5 Data properti mekanik material penyusun rangka mesin [6] } \\
\hline Material & \multicolumn{2}{c}{ Steel } \\
\hline \multirow{3}{*}{ Mechanical } & Mass Density & $7,85 \mathrm{~g} / \mathrm{cm}^{3}$ \\
Properties & Yield Strength & $207 \mathrm{MPa}$ \\
& Ultimate Tensile Strength & $345 \mathrm{MPa}$ \\
& Young's Modulus & $220 \mathrm{GPa}$ \\
Stress & Poisson's Ratio & $0,275 \mathrm{ul}$ \\
& Shear Modulus & $86,2745 \mathrm{GPa}$
\end{tabular}

\section{3a Pre-Processing}

Desain rangka mesin yang telah dibuat dalam bentuk tiga dimensi kemudian diuji kelayakannya dalam menerima beban, adapun langkah berikutnya adalah menentukan constraint dilakukan dengan acuan posisi dari tumpuan yang ada pada produk desain yang telah dimodelkan (Gambar 3.5). Constraints dapat berupa fixed constraints, pin constraints, dan friction constraints. Selain itu, pembebanan pada rangka diatur dengan menggunakan data massa dari komponen yang membebani frame. Massa hopper, motor listrik, dan speed reducer berturut-turut memiliki nilai $6 \mathrm{~kg}, 9,3 \mathrm{~kg}$, dan $7,9 \mathrm{~kg}$.

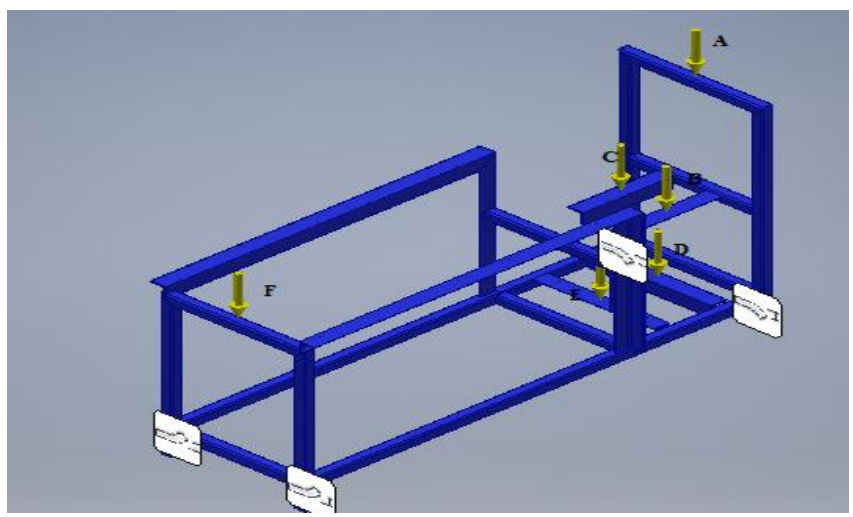

Gambar 3.5 Penempatan gaya pembebanan dan constraint pada rangka 
Keterangan gambar:

$\mathrm{A}$ = gaya yang diberikan $58,86 \mathrm{~N}$; $\mathrm{B}$ dan $\mathrm{C}=$ gaya yang diberikan $79,50 \mathrm{~N} ; \mathrm{D}$ dan $\mathrm{E}$ = gaya yang diberikan $91,23 \mathrm{~N}$.

\section{3b Processing}

Meshing (Gambar 3.6) dapat diartikan sebagai proses didiskritisasi model 3D sehingga struktur utama menjadi elemen-elemen yang memiliki ukuran dan jumlah tertentu. Pada simulasi ini, digunakan spesifikasi nilai element dan nodes sebesar 65009 dan 131467.

Proses Running dilakukan setelah seluruh proses praanalisa dan meshing dilakukan.

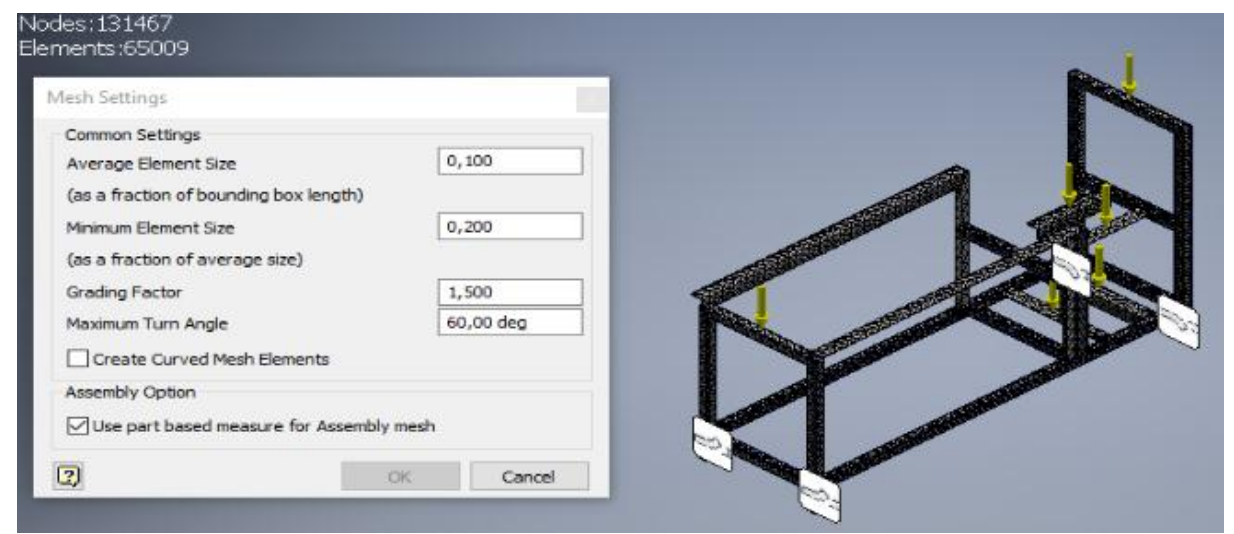

Gambar 3.6 Tampilan mesh pada rangka

Proses Refinement Meshing adalah proses penghalusan jumlah element dan nodes pada bagian yang mengalami tegangan kritis. Pada bagian yang mengalami tegangan maksimum tersebut, dilakukan proses refinement meshing dengan menggunakan fitur local mesh control. Proses ini dilakukan setelah proses running pertama selesai sehingga bisa didapat hasil simulasi yang lebih akurat.

\section{3c Post Processing}

Von misses stress dari simulasi menunjukkan nilai tegangan maksimal yang terjadi akibat pembebanan pada rangka mesin sebesar $18,33 \mathrm{MPa}$ (Gambar 3.7). Nilai tegangan yield untuk material rangka sebesar $207 \mathrm{Mpa}$. Hal ini menunjukkan bahwa nilai pembebanan yang ditimbulkan oleh adanya komponen hopper, motor listrik, dan speed reducer masih berada di bawah tegangan yield dari material penyusun rangka. Displacement yang ditimbulkan dari pembebanan menunjukkan nilai $0,99 \mathrm{~mm}$ dengan nilai safety factor 15 unit less (uI).

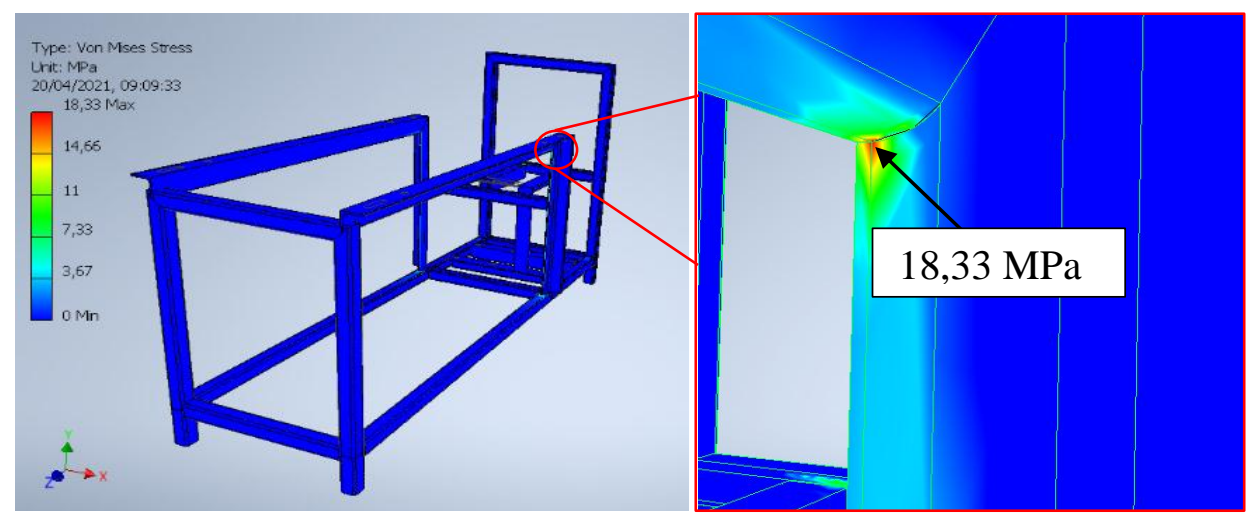

Gambar 3.7 Lokasi von Mises stress tertinggi pada struktur rangka

Fabrikasi mesin hasil rancangan dilakukan dengan menggunakan metode manufacturing konvensional. Gambar 3.8a menunjukkan tampak atas dari mesin penyortir yang telah 
difabrikasi. Terdapat empat jenis grade untuk membedakan kualitas buah duku berdasarkan ukuran diameternya. Grade 1, 2, 3, dan 4 berturut-turut digunakan untuk menampung buah duku berdiameter 19-22 mm, 23-27 mm, 28-34 mm, dan lebih dari $34 \mathrm{~mm}$. Buah duku yang berada pada bagian hopper akan bergerak turun mengikuti arah bidang miring komponen hopper menuju bagian v-belt pensortir. Bagian v-belt pensortir yang bergerak berputar dengan kecepatan $80 \mathrm{rpm}$ akan mendorong buah ke arah grade yang sesuai dengan rentang diameter buah duku. Penyortiran berlangsung dari kualitas grade 1 menuju grade 4 secara berurutan dengan kapasitas mencapai $400 \mathrm{~kg} / \mathrm{jam}$.

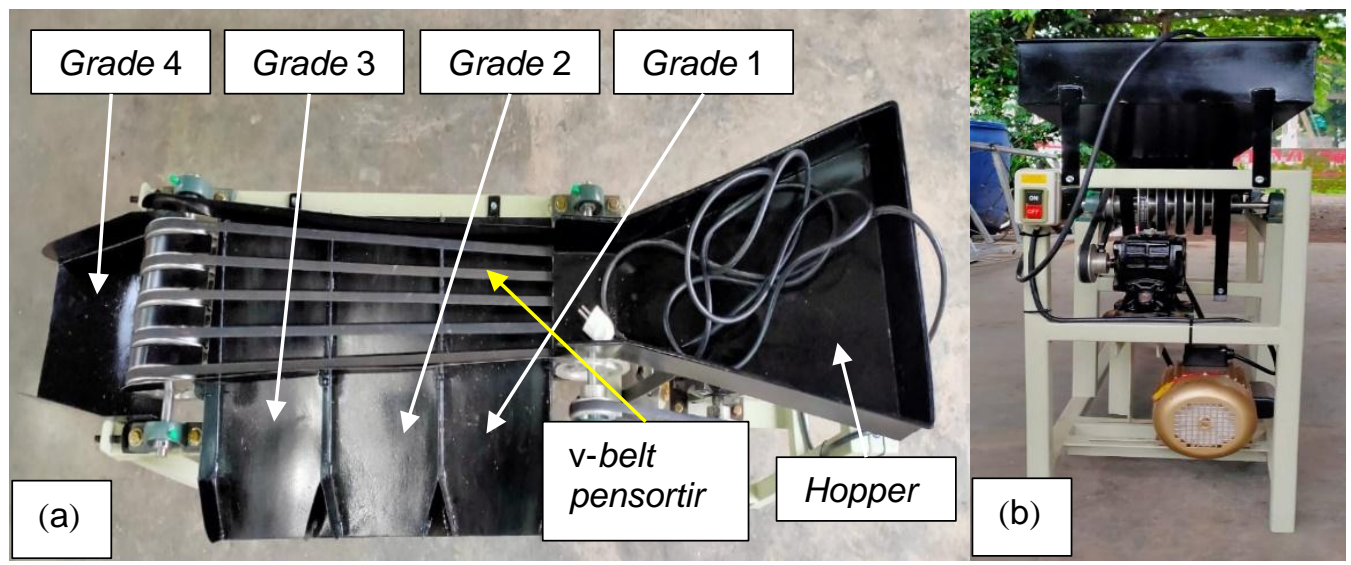

Gambar 3.8 (a) konfigurasi penempatan belt dan grade kualitas buah dan (b) susunan penempatan hopper, speed reducer, dan motor listrik

Hasil pengujian mesin dilakukan dengan cara menyortir buah duku pada grade pertama hingga grade ketiga dengan bobot sampel buah sebesar dua kilogram, pengujian dilakukan sebanyak tiga kali kemudian dihitung nilai rata-ratanya. Persentase keberhasilan pada masing-masing grade dihitung menggunakan Persamaan (3).

$$
T S_{i}: \frac{\text { massa buah yang tersortasi }(\mathrm{kg})}{\text { massa buah yang disortasi }(\mathrm{kg})} \times 100 \%
$$

Tabel 3.6 menunjukkan persentase keberhasilan penyortiran buah duku untuk tiap grade yang ada.

Tabel 3.6 Perbandingan persentase keberhasilan proses penyortiran

\begin{tabular}{|c|c|c|c|}
\hline \multirow[t]{2}{*}{ No } & Jenis grade & \multicolumn{2}{|c|}{$\%$ keberhasilan rata-rata } \\
\hline & & $\begin{array}{c}\text { Mesin penyortir } \\
\text { berdasarkan ukuran } \\
\text { diameter }\end{array}$ & $\begin{array}{c}\text { Mesin penyortir } \\
\text { berdasarkan } \\
\text { prinsip bidang } \\
\text { miring }\end{array}$ \\
\hline 1 & Grade 1 & $100 \%$ & $100 \%$ \\
\hline 2 & Grade 2 & $86,6 \%$ & $50,1 \%$ \\
\hline 3 & Grade 3 & $99 \%$ & $80,1 \%$ \\
\hline
\end{tabular}

Berdasarkan data pada Tabel 3.6, diperoleh performa terbaik mesin penyortir sebesar $100 \%$ untuk menyortir buah duku pada rentang diameter 19-22 mm. Kegagalan penyortiran pada grade 2 dan 3 kemungkinan disebabkan oleh kecepatan putaran belt penyortir sebesar 80 rpm yang kurang sesuai untuk menyortir buah duku dengan ukuran pada rentang $23-27 \mathrm{~mm}$ dan 28-34 mm. Akan tetapi, dengan metode pengujian yang sama, persentase keberhasilan penyortiran mesin penyortir buah duku dengan parameter diameter buah memiliki nilai yang lebih besar dibandingkan dengan mesin penyortir buah duku yang menggunakan mekanisme bidang miring dengan perbandingan tiap grade secara berurutan sebesar 1:1; 1,72:1; dan 1,23:1. Selain itu, berdasarkan hasil pengujian mesin penyortir berdasarkan ukuran diameter buah tidak menimbulkan kerusakan pada kondisi fisik buah. Hal ini dimungkinkan karena luas area kontak buah dan permukaan belt sortasi berlangsung cukup 
singkat sehingga meminimalisasi adanya kontak yang memicu timbulnya kerusakan pada buah duku.

\section{KesimpUlan}

Pembuatan konsep mesin penyortir buah duku Lansium parasiticum menggunakan metode five step method telah berhasil dilakukan. Konsep terbaik dari tiga jenis desain rancangan dipilih dengan menggunakan metode product champion. Analisis FEA pada rangka mesin menggunakan software autodesk inventor 2017 menunjukkan nilai von Misses stress sebesar $18 \mathrm{MPa}$ yang lebih kecil dibanding yield strength material penyusun rangka sebesar $207 \mathrm{MPa}$, displacement yang terjadi sebesar $0,99 \mathrm{~mm}$ dengan nilai safety factor 15 . Hal ini menunjukkan desain struktur rangka mesin masih dalam kategori aman untuk nilai pembebanan yang diberikan. Mesin penyortir buah duku berdasarkan ukuran diameter yang dirancang menggunakan metode pengembangan konsep desain five step method memiliki nilai persentase keberhasilan penyortiran yang lebih baik dibandingkan mesin penyortiran yang menggunakan prinsip bidang miring dengan nilai perbandingan keberhasilan pada grade 1, 2, dan 3 secara berurutan sebesar 1:1; 1,72:1; dan 1,23:1 dengan kapasitas penyortiran mencapai $400 \mathrm{~kg} / \mathrm{jam}$.

\section{DAFTAR PUSTAKa}

[1] M. Y. Sri Ratna Komala, Imron Zahri, "Analisis Usaha Tani Duku dan Kontribusinya Terhadap Pendapatan Rumah Tangga Petani di Kabupaten Ogan Komering Ilir," J. Agribisnis dan Ind. Pertan., vol. 6, no. 55, pp. 147-160, 2007.

[2] W. Warji, S. Asmara, and S. Suharyatun, "Rancang Bangun Dan Uji Kinerja Mesin Sortasi Buah Duku," J. Keteknikan Pertan., vol. 21, no. 2, p. $21989,2007$.

[3] A. Irfan and M. Tajalli, "Rancang Bangun dan Uji Kinerja Mesin Sortasi Duku dengan Kerucut Berputar," J. Penelit. dan Pengabdi. Kpd. Masy. UNSIQ, vol. 7, no. 1, pp. 84-93, 2020, doi: 10.32699/ppkm.v7i1.1060.

[4] K. T. Ulich, Product design and development. New York, 2012.

[5] G. Catalin, "Materials Selection For An Engineering Application Using MultipleCriteria Decision Analysis," Proc. Manuf. Syst., vol. 10, no. 2014, pp. 141-146, 2015.

[6] M. Ashby, "Material and Process Selection Charts," Cambridge Univ., vol. 2, p. 42, 2010.

[7] I. Priadythama, B. Suhardi, and I. Adiasa, "Further study on a short wheel base recumbent bike frame using simulated finite element analysis," 2016 2nd Int. Conf. Ind. Mech. Electr. Chem. Eng. ICIMECE 2016, pp. 219-224, 2017, doi: 10.1109/ICIMECE.2016.7910461.

[8] J. F. Dues, "Stress analysis for novices using autodesk inventor," Proc. 2006 ASME Int. Mech. Eng. Congr. Expo. IMECE2006 - Mech. Eng. Technol. Dep. Heads, pp. 38, 2006, doi: 10.1115/IMECE2006-14569.

[9] R. Păunescu, "Tools And Techniques For Improving The Modular Fixture Design In Autodesk Inventor," J. Ind. Des. Eng. Graph., vol. 10, 2015.

[10] Robles,A.L.,Gaytan,A.,Pena,J.A., "Structural design of an agricultural backhoe using TA, FEA, RSM and ANN," Comput. Electron. Agric., vol. 172, no. July 2019, p. 105278, 2020, doi: 10.1016/j.compag.2020.105278.

[11] Nurato.,Majlan,Herianto.,Daud,Wan., "Finite element analysis for stress distribution in a proton exchange membrane fuel cell stack," Int. J. Integr. Eng., vol. 11, no. 7, pp. 233-240, 2019, doi: 10.30880/ijie.2019.11.07.029.

[12] S. O. Afolabi, B. I. Oladapo, C. O. Ijagbemi, A. O. M. Adeoye, and J. F. Kayode, "Design and finite element analysis of a fatigue life prediction for safe and economical machine shaft," J. Mater. Res. Technol., vol. 8, no. 1, pp. 105-111, 2019, doi: 10.1016/j.jmrt.2017.10.007. 